\title{
Evaluations of Two Reinforced Polymers Used as Metal-Free Substructures in Fixed Dental Restorations
}

\author{
CARMEN BIRIS ${ }^{1}$, EDWIN SEVER BECHIR ${ }^{1}$, ANAMARIA BECHIR ${ }^{2}$, FARAH CURT MOLA ${ }^{1 *}$, ADRIAN VIOREL BADIU ${ }^{3}$, \\ CRISTIAN OLTEAN ${ }^{4}$, CLAUDIA ANDREESCU², CHERANA GIOGA ${ }^{2}$ \\ ${ }^{1}$ Medicine and Pharmacy University of Tirgu Mures, Faculty of Dentistry, 38 Gheorghe Marinescu Str., 540142, Tirgu Mures, \\ Romania \\ ${ }^{2}$ Titu Maiorescu University of Bucharest, Faculty of Dentistry, 67A Gheorghe Petrascu Str.,031593, Bucharest, Romania \\ ${ }^{3}$ Dental Laboratory, 68 General Gheorghe Manu Str., 900674, Constanta, Romania \\ ${ }^{4}$ Iuliu Hatieganu Medicine and Pharmacy University of Cluj-Napoca, Faculty of Dentistry, Louis Pasteur Str., 400349, Cluj Napoca, \\ Romania
}

The development of new classes of dental materials determined the apparition of reinforced polymers, as BioHPP and Trinia, used for core in non-metallic prosthetic restorations, including in implants non-metallic superstructure. The purpose of the study was to present the results of the comparative clinical trials referring to the use of BioHPP and Trinia resins as core in fixed prosthetic rehabilitation. The researches were performed on 33 patients in which we realized 71 fixed prosthetic restorations. According to the six evaluation criteria used in research, we conducted biannual monitoring meetings over two and half years period for registrations of comparative results in the use of these two reinforced polymers as core. The results of the study demonstrated that both type of these materials exhibit a certain degree of elasticity and presents many advantages, therefore these represent a beneficial acquisition in patients oral health.

Keywords: BioHPP, Trinia, fixed prosthetic restorations, comparative evaluation

The prosthetic restorations are currently achieved of increasingly evolved materials, in accordance with the biofunctional and biomechanics requirements of the orofacial system rehabilitation $[1,2]$. The problematic aesthetics of dental alloys and their mechanical, thermal, electrical, allergenic and biological properties induced the developing of researches regarding the obtaining of compatible non-metallic biomaterials. Among these are included BioHPP and Trinia reinforced polymers for nonmetallic restorations. BioHPP-Bredent is a polymer based on polyether-ether-ketone (PEEK) and is used in dentistry for realization of the fixed and movable core, including superstructure on dental implants. The strength of BioHPP is the consequence of the filler with a special ceramic of the very small grain size (between $0.3-0.5 \mu \mathrm{m}$ ), introduced into the polymer structure for the optimisation of mechanical properties, by producing constanthomogeneity due to the grain size, which is an important prerequisite for consistent quality [3]. The aspect of BioHPP polymer and of restorations achieved by BioHPP polymer are presented in figure 1 [4].
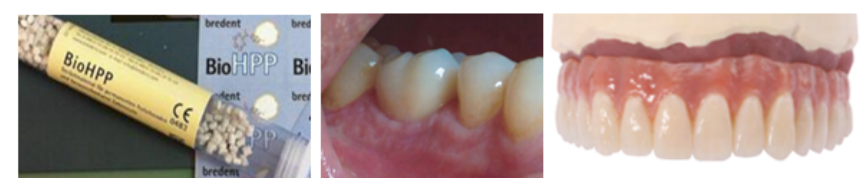

Fig. 1. Presentation of BioHPP polymer (Bredent); fixed and movable restorations with BioHPP [2]

Trinia-Bicon is a CAD/CAM multi-dimensional polymer, reinforced with multi-layered glass fiber kept together by epoxy resin. This biomaterial present low specific weight, is machinable and non-combustible, with high bending and compressive strengthand and is used for the achievement of crowns and bridges on dental or implant-supported abutments, but also for framew ork for movable restorations with implant aggregation (fig. 2) [5].

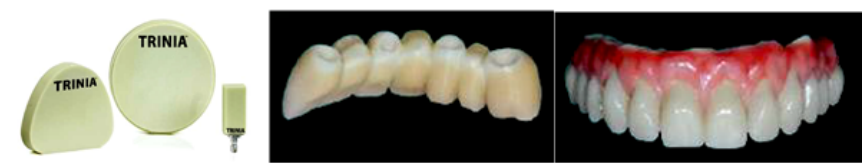

Fig. 2. Aspect of Trinia discs and cube; fixed and movable restorations on implants with Trinia [4]

Dentists are confronted daily with treatment dilemmas for their patients and ideally, the treatment decisions should be based on scientific evidence, combined with the patient desires and the clinician's experience [6]. Rating scales were developed for several factors that were considered relevant to the problem of clinically evaluating dental restorative materials [7]. In order to carry out a correct clinical investigation of dental materials and/or techniques, most researchers use the Ryge criteria for assessing the studied restorations. In 1980, Ryge published the measurement scale as a standardized method for the clinical evaluation of the restorations [8]. Researchers often adapt the criteria in an effort to make them more discriminating for modern restorative materials, with the consequence that there are many so called modified Ryge criteria in use [9].

The purpose of the study was to evaluate comparatively the observed differences in the registered results of the clinical trial after the application of Ryge modified criteria's, referring to use as core of BioHPP and Trinia reinforced polymers in fixed prosthetic rehabilitation.

\section{Experimental part}

Material and methods

The researches were conducted during the period 20142017 in the Dental Medicine Faculties of Tirgu-Mures, Bucharest and Cluj-Napoca Universities, respectivelly in Constanta. The 33 selected patients (17 females and 16 males) were aged between 35 and 54 years ( 44.5 years \pm 9.5 years). The selected group of patients signed the informed consent for participation after having provided a

\footnotetext{
* email: farah.curtmola@yahoo.com; Phone: +40 755972944
} 
complete explanation of the aim of study and committed to attend the biannual recalls for two and half years. After recruitment, oral hygiene instructions were given to all the patients and prophylaxis was performed to establish optimal plaque control and gingival health. Each selected patient had the need at least two of fixed restoration on natural or implant abutments, in order to achieve at least two fixed restorations in the same oral cavity, one of BioHPP core and one of Trinia core. The inclusion criteria in this study were represented by the patients aged 35-54 years, with dental conditions which requiring oral rehabilitation with at least two fixed restorations (FRs) on natural tooth or/and implant abutments, with healthy overall condition and with good dental hygiene (with maxim plaque index $=1$ ). The exclusion criteria were represented by not proper age, smokers, pregnancy, disabilities, systemic diseases, severe medical complications, premalignant and malignant lesions, atypical gingival proliferation, soft tissues/tongue tissues hyperplasia, heavy occlusal contacts or bruxism, allergic history concerning methacrylates, plaque index higher than 1 . The clinical and technical procedures for achievement the fixed prosthetic restorations with BioHPP and Trinia core were standardized before the start of the investigation, after a written detailed protocol.

We performed 71 crowns and bridges, 36 restorations on 44 natural teeth and 35 implant-supported fixed restorations on 42 implants. All restorations were achieved by same dental technician of the research team. Furthermore, aiming to secure a blind study, patients and examiners were unaware of any data from the randomization process. In figure 3 are presented the distribution of the patients by gender, age, number of fixed restorations (FR) and number of abutments.

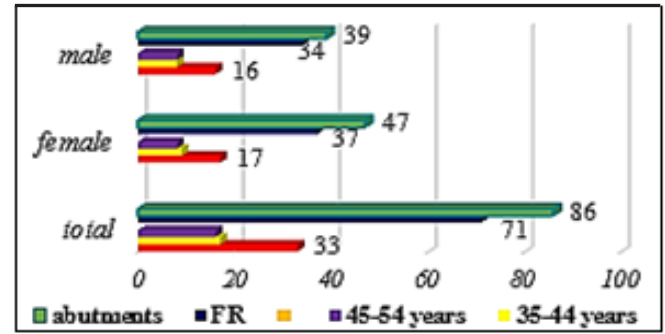

Fig. 3. Distribution of the patients by gender, age, number of fixed restorations and of abutments

The steps for the achievement of BioHPP core were: abutments preparation (teeth/impresion posts), impression of prosthetic field, impression pouring, obtaining the stone casts, modelling the wax pattern of BioHPP core, packing in special cuvette and with special investment material. The mold was preheated and the wax was melted away. BioHPP was heated for 60-90 min (after the dimension of the cuvette) till $800^{\circ} \mathrm{C}$ and then slow cooled at $400^{\circ} \mathrm{C}\left(5^{\circ} \mathrm{C}\right.$ per $\left.\mathrm{min}\right)$. At this temperature, the mold was transfered in for 2 press device and the press plunger was inserted. By raising the lift, the pressing procedure was triggered automatically in vacuum, and than after the pressing, the mold was cooled down to room temperature within 25-35 min. Devesting was realized as usual, and the BioHPP cores were processed and adapted on the movable abutments of models. The BioHPP cores were veneered with the light-cured composite resin Gradia GC for indirect restorations and light-cured in Sibari SR 620 lightpolymerizator and than, the occlusion was adjusted. In the cases of implant-suported abutments, the BioHPP core were blasted, a special varnish were applied inside of the cores and than were light-cured and cemented on the implant abutments extra-oraly in laboratory with Variolink dual cement. Cementations of fixed restorations (crowns or bridges) with BioHPP core were performed in dental office with Variolink dual cement too. Phases in the achievement of a restoration with BioHPP core are presented in figure 4.
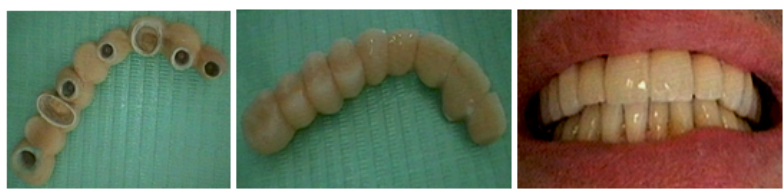

Fig. 4. Aspect of an upper implant-supported fixed restoration with BioHPP core, at insertion in oral cavity

The phases for achievement of fixed restorations with Trinia core were: abutments preparation (teeth/impresion posts), impression of prosthetic field, impression pouring, obtaining the stone casts, scanning of casts, computerized design of the Trinia core with Pi Dental CAD/CAM Processing System, milling the Trinia discs with Cobra 4 Pi Denta milling machine, the covering of Trinia core with the aesthetic layers of Gradia GC composite resin and light-curing in Sibari SR 620 lightpolymerizator. Occlusion was adjusted. In the cases of implant-suported abutments, the cementation of Trinia core with Gradia GC layers on the implant abutments were effectuated in the laboratory, with AGC Cem-W ieland self-curing resin. In dental office were realized the insertion of the cemented superstructures on Bicon implants. The cementation of fixed restorations (crown or bridge) with Trinia core were accomplished in dental office with AGC Cem-Wieland self-curing resin too. If it was necessary, a new occlusal adaptation was performed, followed by finishing and polishing. Phases in the achievement of a fixed restoration on Bicon implant with Trinia core are presented in figure 5-7.
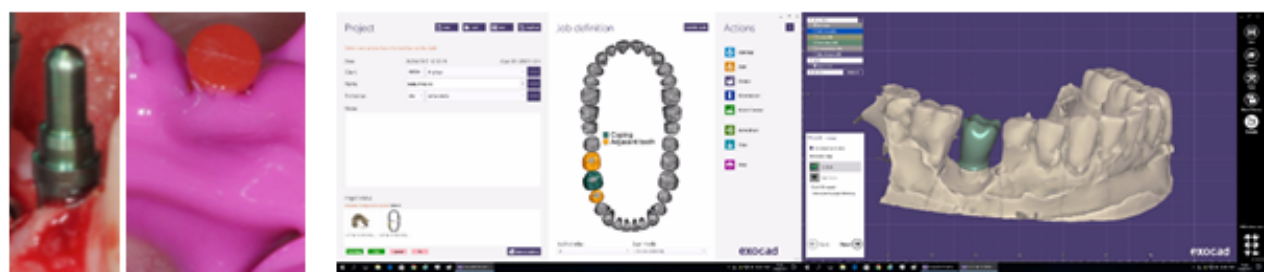

Fig. 5. Implant-post impression; Computerized design of the future crown with Trinia core in the 4.6 tooth area

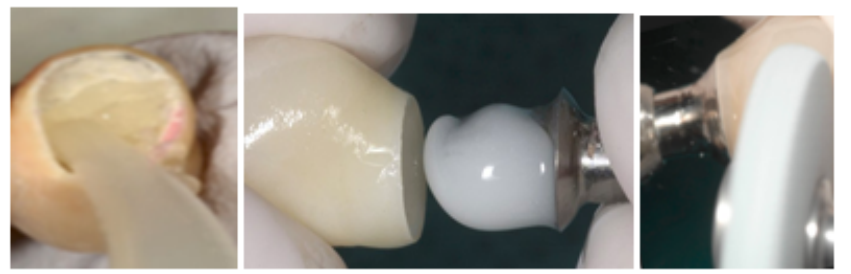

Fig. 6. Cementation of restoration on implant abutment in laboratory and finishing after cementation

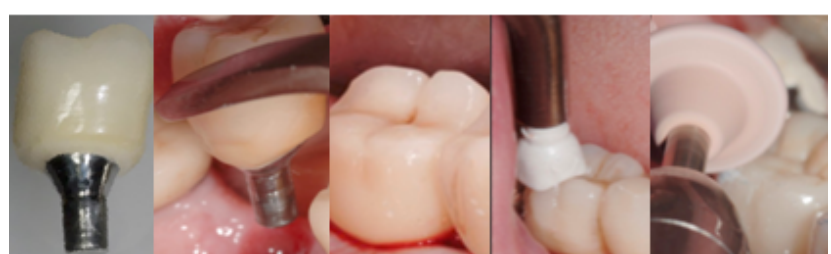

Fig. 7. Aspect of cemented in laboratory restoration on implant abutment, insertion in implant, final insertion on Bicon implant, occluzal adaptation and finishing 


\begin{tabular}{|c|c|c|c|}
\hline & Criteria & Score & Characteristics \\
\hline \multirow[t]{4}{*}{1.} & \multirow{4}{*}{$\begin{array}{l}\text { Discolorations in } \\
\text { prosthetic } \\
\text { restorations }\end{array}$} & A & No evident discoloration \\
\hline & & $\bar{B}$ & Slight discoloration \\
\hline & & $\mathrm{C}$ & Evident discoloration \\
\hline & & D & Gross staining \\
\hline \multirow[t]{4}{*}{2.} & \multirow{4}{*}{ Surface texture } & $\overline{\mathrm{A}}$ & Smooth gurface \\
\hline & & $\mathrm{B}$ & Slightly rough \\
\hline & & $\mathrm{C}$ & Rough, cannot be refinished \\
\hline & & $\mathrm{D}$ & Deeply pitted surface \\
\hline \multirow[t]{4}{*}{3.} & \multirow{4}{*}{ Marginal integrity } & $\overline{\mathrm{A}}$ & Excellent, explorer does not catch or penetrate \\
\hline & & $\mathrm{B}$ & Explorer catches, slight cervice margin \\
\hline & & $\mathrm{C}$ & Evident crevice at margin \\
\hline & & $\mathrm{D}$ & Mobile, fractured or missed restoration \\
\hline \multirow[t]{4}{*}{4.} & \multirow{4}{*}{$\begin{array}{l}\text { Gum problems in } \\
\text { conformity with } \\
\text { Loe \& Silness } \\
\text { Gingival Index } \\
\text { (GI) }\end{array}$} & $0=\mathrm{A}$ & Normal gingiva \\
\hline & & $\mathrm{l}=\mathrm{B}$ & $\begin{array}{l}\text { Mild inflammation: Slight change in color, slight edema; } \\
\text { No bleeding on probing }\end{array}$ \\
\hline & & $2=\mathrm{C}$ & Moderate inflammation: Redness, edema, glazing, bleeding on probing \\
\hline & & $3=\mathrm{D}$ & $\begin{array}{l}\text { Severe inflammation: Marked redness, edema, ulceration; } \\
\text { Tendency to spontaneous bleeding }\end{array}$ \\
\hline \multirow[t]{2}{*}{5.} & \multirow{2}{*}{$\begin{array}{l}\text { Allergic reactions } \\
\text { of soft tissues }\end{array}$} & $\overline{\mathrm{A}}$ & No allergic reactions \\
\hline & & $\mathrm{B}$ & Present allergic reactions \\
\hline \multirow[t]{2}{*}{6.} & \multirow{2}{*}{$\begin{array}{l}\text { Fissure or fracture } \\
\text { of the restoration }\end{array}$} & $\overline{\mathrm{A}}$ & No fissure or fracture \\
\hline & & $\bar{B}$ & Present fissure or fracture \\
\hline
\end{tabular}

Table 1

MODIFIED RYGE CRITERIA USED IN THIS STUDY

\begin{tabular}{|c|c|c|c|c|c|c|c|c|c|c|c|c|c|}
\hline \multirow[b]{2}{*}{ Criterias } & & \multicolumn{6}{|c|}{$\overline{\text { BioHpp core dental restorations }=36}$} & \multicolumn{6}{|c|}{ Trinia core dental restorations $=\mathbf{3 5}$} \\
\hline & & $\begin{array}{c}\text { Inser- } \\
\text { tion } \\
\end{array}$ & $\begin{array}{c}6 \\
\text { months }\end{array}$ & $\begin{array}{c}12 \\
\text { months }\end{array}$ & \begin{tabular}{|c|}
18 \\
months
\end{tabular} & $\begin{array}{c}24 \\
\text { months }\end{array}$ & $\begin{array}{c}30 \\
\text { months }\end{array}$ & $\begin{array}{c}\text { Inser- } \\
\text { tion } \\
\end{array}$ & $\begin{array}{c}6 \\
\text { months }\end{array}$ & $\begin{array}{c}12 \\
\text { month: }\end{array}$ & $\begin{array}{c}18 \\
\text { months }\end{array}$ & \begin{tabular}{|c|}
24 \\
months
\end{tabular} & \begin{tabular}{|c|}
30 \\
months
\end{tabular} \\
\hline \multirow{4}{*}{$\begin{array}{l}\text { Discolorations } \\
\quad \text { in FRs }\end{array}$} & $\overline{\mathrm{A}}$ & $100 \%$ & $\overline{100 \%}$ & $\overline{100 \%}$ & $100 \%$ & $100 \%$ & $97.22 \%$ & $100 \%$ & $100 \%$ & $100 \%$ & $100 \%$ & $100 \%$ & $100 \%$ \\
\hline & B & - & - & - & - & - & $2.77 \%$ & - & - & - & - & - & - \\
\hline & $\mathrm{C}$ & - & - & - & - & - & - & - & - & - & - & - & - \\
\hline & $\mathrm{D}$ & - & - & - & - & - & - & - & - & - & - & - & - \\
\hline \multirow{4}{*}{ Surface texture } & $\overline{\mathrm{A}}$ & $100 \%$ & $\overline{100 \%}$ & $\overline{100 \%}$ & 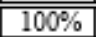 & $\overline{100 \%}$ & $97.22 \%$ & $100 \%$ & $100 \%$ & $100 \%$ & 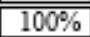 & 100\% & $100 \%$ \\
\hline & B & - & - & - & - & - & $2.77 \%$ & 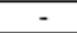 & - & - & - & - & - \\
\hline & $\mathrm{C}$ & - & 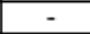 & - & - & - & - & - & - & - & - & - & - \\
\hline & $\mathrm{D}$ & - & - & - & - & - & - & - & - & - & - & - & - \\
\hline \multirow{4}{*}{$\begin{array}{l}\text { Marginal } \\
\text { integrity }\end{array}$} & $\overline{\mathrm{A}}$ & $\overline{00 \%}$ & $100 \%$ & $100 \%$ & $100 \%$ & $97.22 \%$ & $94.44 \%$ & $\overline{100 \%}$ & $100 \%$ & $100 \%$ & $100 \%$ & $100 \%$ & $100 \%$ \\
\hline & B & - & - & - & - & $2.77 \%$ & $5.55 \%$ & - & - & - & - & - & - \\
\hline & $\mathrm{C}$ & - & - & 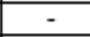 & - & - & - & - & - & - & - & - & - \\
\hline & D & - & - & - & - & - & - & 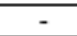 & - & 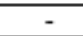 & - & $\begin{array}{l}- \\
-\end{array}$ & - \\
\hline \multirow{4}{*}{$\begin{array}{l}\text { Gum problems } \\
\text { in conformity } \\
\text { with Loe\&Silness } \\
\text { Gingival Index GI }\end{array}$} & $0=\mathrm{A}$ & $\bar{~} 100 \%$ & $\overline{100 \%}$ & $\overline{100 \%}$ & $100 \%$ & $97.22 \%$ & $97.22 \%$ & $100 \%$ & $100 \%$ & $\overline{100 \%}$ & $100 \%$ & $100 \%$ & $100^{\circ}$ \\
\hline & $1=B$ & - & - & - & - & $2.77 \%$ & $2.77 \%$ & - & - & - & - & - & - \\
\hline & $2=C$ & - & - & - & - & - & - & - & - & - & - & - & - \\
\hline & $3=D$ & - & - & - & - & - & - & - & - & - & - & - & - \\
\hline \multirow{2}{*}{\begin{tabular}{|c|} 
Allergic reactions o \\
the soft tissues \\
\end{tabular}} & $\overline{\mathrm{A}}$ & $100 \%$ & $\overline{100 \%}$ & $100 \%$ & $100 \%$ & $\overline{1100 \%}$ & $100 \%$ & $100 \%$ & $100 \%$ & $100 \%$ & $100 \%$ & $100 \%$ & $100^{\circ}$ \\
\hline & B & - & - & - & - & - & - & - & - & - & - & - & - \\
\hline \multirow{2}{*}{$\begin{array}{c}\text { Fissure/fracture in } \\
\text { restoration }\end{array}$} & $\overline{\mathrm{A}}$ & $\bar{~} 100 \%$ & $\overline{1100 \%}$ & $\overline{1100 \%}$ & $\overline{100 \%}$ & $\overline{1100 \%}$ & $100 \%$ & $\bar{~} 100 \%$ & $\bar{~} 100 \%$ & $100 \%$ & $100 \%$ & $100 \%$ & 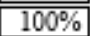 \\
\hline & $B$ & & & & & & & & & & 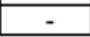 & 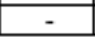 & \\
\hline
\end{tabular}

Table 2

RECORDED RESULTS AFTER PROCESSING

OF DATA, IN

REFERENCE TO THE CRITERIA SET
The purpose of good occlusal adaptation was to reduce the apparition risk of damage in interrelated tissues of the masticatory system, and to enchance the circumstances for realisation of a healthy function. After the adaptation period to crowns and bridges achieved of BioHPP and Trinia core ( 2 weeks), we conducted biannual monitoring meetings, over two and half years period (also six sessions), with the registrations of comparative results after the used criteria. In total were carried 6 registrations of the selected criteria in the included patients to study. Modified Ryge criteria used in this study are presented table 1. Alfa (A) value indicated that conditions were clinically ideal; Bravo (B) ratings indicated clinical acceptability; Charlie (C) and Delta (D) ratings were not noted at baseline monitoring meetings, at six months and at one year, because were not conclusive.

\section{Results and disscusions}

The registrations in according with the detailed criteria, were realized after the examinations of patients, during the six monitoring meetings. Table 2 summarizes the recorded results in percentages and in reference to the criteria set, after the evaluation period of two and half years.

At the first, second, third and fourth recall (at 6, 12, 18 and 20 months), all restorations received alpha score (A) with respect to each evaluation criteria. At the fifth recall, we observed in one single restoration with BioHPP core $(=2.77 \%)$ the modification of marginal integrity and gum problems. At the sixth recall, we observed in one single restoration with BioHPP core $(=2.77 \%)$ the discoloration, modification of surface texture and gum problems, but modification in marginal integrity was depisted at two fixed restoration $(=5.55 \%)$. The results of study releaved that after 30 months of monitoring no modifications were depisted in the fixed restorations with Trinia core. Allergic reactions of the oral mucosa soft tissues in contact with the fixed restorations were not noted $(=0 \%)$. After six follow-up, all restorations were in function and no fissures or fractures were detected. At the end of study, the percentage of the differences in the fixed restorations with BioHPP or Trinia core were not significant and demonstrated the good clinical performance of both reinforced polymers.

We note that after all monitoring sessions, only one patient experienced more than one of the criteria listed above, and this patient represented our limitcase. In figure 8 is presented the image of intraoral aspect of fixed restorations in P.R. pacient (53year old) with a crown with BioHPP core on second lower right premolar (4.5) and a superstructure with Trinia core on Bicon implant in the area of 4.6. The image was realized at sixth monitoring session. Differences in discolorations, in surface texture and in marginal integrity between the two fixed restorations are visible. This case reprezent the limit case of our study.

The results of the study demonstrated that both type of reinforced polymers presents many advantages, therefore 


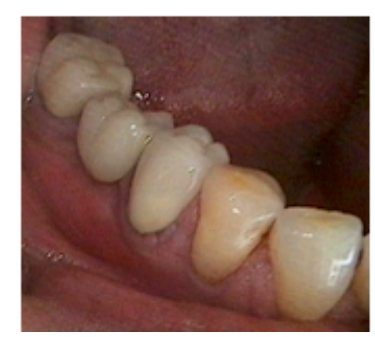

Fig. 8. Aspect of the two fixed restorations on right lower posterior area at the sixth monitoring session

these materials which exhibit a certain degree of elasticity, represent a beneficial acquisition to the oral health of patients. Also, reinforced polymers, because their resiliency, elasticity and ultralight biocompatibility, are more efficient, aesthetic and cost-effective alternative to casted metal core/frameworks or milled in zirconia/titanium frameworks. In addition, restored edentations with milled Trinia core crowns or bridges, realized by extra-orally cemented fixed restorations on Bicon implant abutments represent a facility both for physicians and for patients comfort.

The new classes of dental polymers are reinforced with special glass beads or chopped glass fibers. Glass fibers increase the rigidity of the polymers to a value approximately equal to that of a thermally hardened thermoplastic denture base, but these glass fibers used for reinforcement also have disadvantages and patients undergoing such restorations should be warned not to erode the external and internal surface to avoid free exposure to the extremities of these glass fibers, which causes irritation of the oral mucosa on which they are inserted [10-12]. Of all evaluated restorations, we observed only in the limit case, modification in crown surfaces texture, gum problems, respectively increased Loe and Silness Gingival Index.

Reinforced polymers have a major advantage over dental ceramics, through their reduced impact force on implants (approximately 50\%) [13,14]. Light-curing polymeric which coate exterior of BioHPP and Trinia core, allows color changes and small repairs of restorations which can be made in dental office [15].

BioHPP reinforced polymer is semi-crystalline, thermoplastic, pigmented resin. The base material is polyetheretherketone (PEEK), which was developed as a veneer-compatible framew ork material. The good material properties are not impaired during processing [16]. After the researches of Vosshans et al [17], BioHPP as a core/ framework material have a lot of advantages: restorations with a low specific weight, elasticity similar to that of bone, sock-absorbing effect, metal-free restorations, low material fatigue, no viscoplastic fractures, high biocompatibility, low plaque accretion, no corrosion.and colour stability.

Trinia polymeric material, due to its anisotropy and balanced blending of components (which give balanced viscoelasticity), is a biopolymer that can be used successfully in rehabilitation of the affected functions of the oro-facial system by making resistant and aesthetic prosthetic restorations, functionally similar to the anatomical structures they replace, having incomparably better properties than restorations made of metallic or ceramic materials $[18,19]$. One of Trinia's greatest attributes is its high flexural strength of $393 \mathrm{MPa}$ and compressive strength of $374 \mathrm{MPa}$ (parallel) and $339 \mathrm{MPa}$ (perpendicular). Stresses modulus is also another feature that adds to the superiority of this material, allowing for excellent tooth-like reproduction [20]. With their characteristics of the nano-hybrid material, Trinia does not retain plaque like other materials [21].
In the last decade, computer-assisted design/computerassisted manufacturing (CAD/CAM) technology has become increasingly popular and fulfills higher patient expectations with regard to more natural and esthetic toothcolored indirect restorations [22,23]. In addition to the timeefficient working process, reduced laboratory time, and economic benefits for both patient and clinician, the use of CAD/CAM technology facilitates quality control and the utilization of dental materials [24]. Today, a large variety of CAD/CAM materials is available, from resin composite and silica-based ceramics to high-strength ceramics $[25,26]$.

The proper use of criteria has a direct effect on the reporting of outcome measurements [27]. Pjetursson et al [28], considered that a crown or a bridge is successful if it remained unchanged and free from all complications over the observation period, and was considered to have survived if itremained in situ with or without modification, over the period of entire observation. Long-term success of dental restorations is attributed to various factors, related to patients individuality (for example, cooperation, type/ size of restoration, nutrition, hygiene, oral environment, bruxism) $[29,30]$.

The use of new class of biomaterials for replacing the absent teeth has become possible after the development of new technologies and of biomaterials with requirements such as lack of corrosion, biocompatibility, resistance and tolerance to the buccal environment $[1,3,31]$. Dental materials biocompatibility represent an important criteria for the patient, clinician, laboratory technician, and manufacturer. Ideally, a dental material that is to be used in the oral cavity should be harmless to all oral tissues, gingiva, mucosa, pulp, and bone [2,32].

\section{Conclusions}

With the limitations of this study, due to the low number of cases, the following conclusions can be draw:

- The type of core-material material did not significally influenced the results.

- The results suggest that the success rate of toothsupported and implant-supported BioHpp and Trinia core crowns/bridges were adequate.

- The technology of the achievement BioHPP and Trinia core is quite complex, requiring both expertise and proper endowment.

- Well-designed studies with larger patient groups and longer follow-up times are needed for the correct comparative trials of restorations with core/framework of BioHPP and Trinia reinforced polymers.

\section{References}

1. ANDREESCU, C. F., GHERGIC, D.L., BOTOACA, O., BARBU, H.M., CERNUSCA-MITARIU, I.S., PATROI, D.N., Mat. Plast., 54, no.1, 2017, p. 32

2.GHIBAN, N., BORTUN, C. M., BORDEASU, I., GHIBAN, B., FAUR, N., CERNESCU, A., HANGANU, S.C., Mat. Plast., 47, no. 2, 2010, p. 240

3.BECHIR, E.S., BECHIR, A., GIOGA, C., MANU, R., BURCEA, B., DASCALU, I.T., Mat. Plast, 53, no.3, 2016, p. 394

4.**file:///C:/Users/user4/Downloads/000534GB_BioHPP_elegance_ Hybridabutments_medical\%20(1).pdf

5.TRINIA_Brochure.pdf

6.BALLINI A, CAPODIFERRO S, TOIA M, CANTORE S, FAVIA G, DE FRENZA G, GRASSI FR, Int J Med Sci. 2007 J un, 6;4(3):174-8

7.SCHMALZ G, RYGE G, Clinical Oral Investigations, 2005, 9(4):215232

8.RYGE G. Clinical criteria. Int Dent J 1980;30:347-58

9.HICKEL, R., ROULET, J.F., BAYNE, S., et al, J Adhes Dent. 2010, 12(4):259-72 
10.http://intranet.tdmu.edu.ua/data/kafedra/internal/stomat_ortop/ classes_stud/en/stomat/ptn/Propaedeutics $\% 20$ of $\% 20$ orthopedic $\%$ 20stomatology/2/08.\%20Plastics.\%20Ceramic\% 20masses\%20and\% 20sitalls..htm

11.SOYGUN, K, BOLAYIR, G, BOZTUG, A. The Journal of Advanced Prosthodontics. 2013, 5(2):153

12.VOJDANI M, GITI R. J ournal of Dentistry. 2015, 16(1 Suppl):1-9

13.J UNG-HWAN LEE, HAE-WON KIM, SEOG-JIN SEO, Journal of Nanomaterials, Vol. 2016, Article ID 3795976, 8 pages

14.HADA T, TAKAHASHI H, KAMIJ O S, IKEDA M, KITAMURA T, HIGUCHI S, SUZUKI T, Published by Elsevier Ltd, 2016, https://doi.org/10.1016/ j.dental.2016.08.048

15.RAINER A, URDANETA RA, MARINCOLA M. J Prosthodont. 2007 JulAug; 16 (4): $311-8$

16.*** https://fr.scribd.com/document/306059425/BioHPP-clinicalresearch-data-pdf

17.VOSSHANS J, SCHELHOVE M, SCHNIEDER F, Zahntech. Mag., 2013, Vol. 17, No. 3, p. 138- 143

18.*** https://www.facebook.com/pg/TriniaMetalFree/about/ ?entry_point=about_section_header $\&$ ref $=$ page_internal

19.*** https://www.accessdata.fda.gov/cdrh_docs/pdf13/K133608.pdf 20.*** http://www.trinia.com/

21.*** https://ww w.dentalaegis.com/cced/2016/10/trinia-the-nextgeneration-of-cad-cam-and-metal-free-restorations

22.RUSU, L.C., PIRTE., A., BORTUN, C,M., HOINOIU, B., PODARIU, A.C, ARDELEAN, L, NEGRUTIU, M.L, SINESCU, C., PLES, H., Rev. Chim. (Bucharest), 66, no. 2,2015, p. 233
23.ANDREESCU, C.F., GHERGIC, D.L., BOTOACA, O., BARBU, H.M., CERNUSCA MITARIU, I.S, PATROI, D.N., Mat. Plast., 54, no.1, 2017,

p. 32

24.*** https://www.aegisdentalnetwork.com/cced/2016/10/adhesivebonding-to-hybrid-materials-an-overview-of-materials-andrecommendations

25.*** SHOFU DENTAL CORPORATION, Compendium of Continuing Education in Dentistry, October 2016, Volume 37, Issue 10, https:// www.dentalaegis.com/cced/2016/10/adhesive-bonding-to-hybridmaterials-an-overview-of-materials-and-recommendations

26.SPITZNAGEL FA, HORVATH SD, GUESS PC, BLATZ MB. J Esthet Restor Dent. 2014;26(6):382-393

27.*** NUSAVICE KJ, Dent Mater. 2012 J an; 28(1):102-11

28.PJ ETURSSON BE, BRAGGER U, LANG NP, et al., Clin Oral Implants Res. 2007;18(Suppl 3):97-113

29.SAVEANU, C.I, DANILA, I., DANILA, V., DRAGOS, O., CHEPTEA, C., Rev. Chim.(Bucharest), 67, no. 11, 2016, p. 2337

30.CRETESCU, I., ROPCIUC, S., AHMADI, M., RADA, O.A., OSTAN, M., Rev. Chim. (Bucharest), 67, 2016, no. 4, p.796

31.HANCU, V., COMANEANU, R.M., COMAN, C., FILIPESCU, A.G., GHERGIC, D.L., COTRUT, M.C., Rev. Chim. (Bucharest), 65, no. 6, 2014, p. 706

32.CIAVOI, G., BECHIR, A., TIG, I., DALAI, C., MANU, R., Mat. Plast., 53, no.2, 2016, p. 247

$\overline{\text { Manuscript received: } 27.11 .2017}$ 